(c) American Dairy Science Association, 2004.

\title{
Purification and Characterization of Intracellular Proteinase from Lactobacillus casei ssp. casei LLG
}

\author{
J. Y. Shin, ${ }^{1, \star}$ W. M. Jeon, ${ }^{2}$ G.-B. Kim, ${ }^{1}$ and B. H. Lee ${ }^{1,3}$ \\ ${ }^{1}$ Department of Food Science and Agricultural Chemistry, McGill University, 21,111 \\ Lakeshore Road, Ste-Anne-de-Bellevue, Quebec Canada H9X 3V9 \\ ${ }^{2}$ Department of Applied Animal Science, Sahmyook University, Seoul, Korea \\ ${ }^{3}$ Food Research \& Development Centre, Agriculture and Agri-Food Canada, \\ St-Hyacinthe, Quebec, Canada J2S 8E3
}

\begin{abstract}
The intracellular proteinase of Lactobacillus casei ssp. casei LLG was isolated in the cytoplasmic fraction with $0.05 M$ Tris-HCl buffer (pH 7.5). The enzyme was purified by the fast protein liquid chromatography system equipped with ion-exchange and gel filtration chromatographies. This proteinase comprised a single monomeric form and had a molecular weight of about 55 $\mathrm{kDa}$ and an isoelectric point near $\mathrm{pH}$ 4.9. The optimum $\mathrm{pH}$ and temperature for the enzyme activity were determined to be $\mathrm{pH} 6.5$ and $37^{\circ} \mathrm{C}$, respectively. The enzyme was inactivated by metal-chelating compounds (EDTA, 1,10-phenanthroline) and less affected by serine proteinase inhibitors (diisopropylfluorophosphate, phenylmethylsulfonyl fluoride). Proteinase activity was increased by $\mathrm{Ca}^{++}, \mathrm{Mn}^{++}$, and $\mathrm{Co}^{++}$, and inhibited by $\mathrm{Cu}^{++}$, $\mathrm{Mg}^{++}$, and $\mathrm{Zn}^{++}$. The activity of this enzyme to hydrolyze casein appeared to be more active on $\beta$-casein than $\alpha_{\mathrm{s} 1^{-}}$ casein and $\kappa$-casein as monitored by polyacrylamide gel electrophoresis.
\end{abstract}

(Key words: Lactobacillus casei, proteinase, purification)

Abbreviation key: LAB = lactic acid bacteria, NSLAB = nonstarter LAB.

\section{INTRODUCTION}

In Cheddar cheese, the starter Lactococcus cells normally reach about $10^{9} \mathrm{cfu} / \mathrm{g}$ after salting stage. In our previous study and others (Lee et al., 1990a; Trépanier et al., 1992a, 1992b; Demarigny et al., 1996; 1990b; Roy et al., 1997; Beresford et al., 2001), the nonstarter lactic acid bacteria (NSLAB) population that was present at low concentrations $\left(<10^{3} / \mathrm{g}\right)$ was increased to about

Received February 15, 2002

Accepted July 22, 2003.

Corresponding author: B. H. Lee; e-mail: byong.lee@mcgill.ca.

*Current address: Dept. of Food and Biotechnology, Chungcheong University, Chungpuk, Korea.
$10^{8-9} \mathrm{cfu} / \mathrm{g}$ after about 3 to 4 mo. The NSLAB was always predominated by the Lactobacillus casei group (Lb. casei / Lactobacillus paracasei / Lactobacillus rhamnosus) in good quality of mature Cheddar, and they were judged to improve cheese flavor, but their contribution to cheese flavor and their origins are still unclear. It appears to be a general trend that $L b$. casei group predominated in later stage of ripening, regardless of cheese types (in particular for semi- and hard type), and this flora is unlikely unique to each plant and each country (Lee et al., 1990a, 1990b; Linberg et al., 1996; Beresford et al., 2001).

Considering the very hostile environment of low temperature $\left(5\right.$ to $\left.6^{\circ} \mathrm{C}\right)$, redox potential, water activity, $\mathrm{pH}$, and lactose, but high salt, it is intriguing how $L b$. casei grows to such large numbers in cheese. Their energy sources and growth factors have been much debated. Lactobacillus casei seems to grow very well in starter cell debris, and their products released by autolysis (Thomas, 1987), peptides (Nath et al., 1973), and glycoproteins of milk fat (Williams and Banks, 1997). It has also been shown that NSLAB grow fast in Cheddar cheese (with a generation time of $8.5 \mathrm{~d}$ at $6^{\circ} \mathrm{C}$ ), thus low levels of contamination will result in their dominance of total cheese flora (Jordan and Cogan, 1993). Randomly amplified polymorphic DNA was also used to detect the concentrations of NSLAB in Cheddar cheese, confirming the predominance of $L b$. paracasei type after 4 to 8 wk of ripening (Fitzsimons et al., 1999).

Several studies have thus been carried out to accelerate Cheddar cheese with selected adjunct live $L b$. casei or Lactococcus lactis cultures or shocked/lysis cultures (El Abboudi et al., 1991; Trépanier et al., 1992a, 1992b; McSweeney et al., 1994; Buist et al., 1998; Kang et al., 1998; Madkor et al., 2000).

During cheese ripening, evidence of autolysis and lysis of $L b$. helveticus and $L b$. casei also occurred naturally by the release of the intracellular enzymes (Dako et al., 1995; Kang et al., 1998; Valence et al., 1998). Thus proteolysis in cheese through both cell envelopeassociated proteinase (PrtP or PrtH) and intracellular 
proteinase, along with more than 10 peptidases (PepN, PepX, PepO, PepQ, PepW, etc.), play a role in development of the desired texture, aroma, and flavor during cheese ripening (Courtin et al., 2002).

The cell-wall-associated proteinases have been reported from Lactococcus lactis ssp. cremoris AC1 (Geis et al., 1985), Lactobacillus delbrueckii ssp. bulgaricus (Kawai et al., 1999), Lactococcus lactis (Buis et al., 1998), and Lactobacillus casei (El Soda et al., 1986; Ezzat et al., 1988; Dhingra and Dutta, 2000). The cellenvelope proteinase genes have also been sequenced from Lactococcus lactis, Lactobacillus paracasei, Lactobacillus helveticus, Lactobacillus delbrueckii, Streptococcus pyogenes, and Streptococcus agalactiae (Siezen, 1999). However, the data on the intracellular proteinases from lactic acid bacteria (LAB) are very limited (Ohmiya and Sato, 1975; Muset et al., 1989; Akuzawa and Okitani, 1995), and their functions are not well known.

Lactobacillus casei ssp. casei LLG expresses a high level of intracellular proteinases and aminopetidases (Arora and Lee, 1994; Habibi-Najafi and Lee, 1994), the combined activity of these enzymes results in the production of cheese flavor compounds (Trépanier et al., 1992a, 1992b; Arora and Lee, 1994; Park et al., 1994; Arora et al., 1995; Christensen et al., 1999). Therefore, purification of the enzyme from LAB and characterization of their properties are considered to be indispensable for elucidation of the mechanisms involved in the processes of texture and flavor formation during cheese ripening and preparation of enzyme-modified cheese (Park et al., 1995; Habibi-Najafi and Lee, 1996).

The intracellular proteinase from $L b$. casei ssp. casei LLG was thus purified to determine the specificity on the caseins and clarify the role of this enzyme for the production of accelerated-ripened cheese and enzymemodified cheese.

\section{MATERIALS AND METHODS}

\section{Chemicals and Materials}

Azocasein, lysozyme from chicken egg white, and mutanolysin from Streptococcus globisporus ATCC 21553 were from Sigma Chemical (St. Louis, MO). Gels, stain dye, and molecular weight markers for the electrophoresis were supplied by Pharmacia (Baie d'Urfe, QC, Canada). All other chemicals were of analytical grade. Ultrafiltration membranes (Centriprep-30) were from Amicon (Beverly, MA). Chromatographic and PD-10 columns were obtained from Pharmacia.

\section{Microorganism and Culture Conditions}

Lactobacillus casei ssp. casei LLG used in this study was isolated from a mature Cheddar cheese and tenta- tively identified by API 50 CHL (Merieux, St-Laurent, QC, Canada). Identification was further achieved by genetic techniques with RFLP and single-strand conformation polymorphism using PCR to amplify specific sequences of aminopeptidase (PepN) genes of Lactobacillus rhamnosus according to our previous method (Lee and Robert, 1997; Belanger, 1998).

Stock culture was maintained in sterile 10\% (wt/vol) skim milk (Difco, Detroit, MI), and working culture was revived from frozen culture by 3 consecutive transfers in the same skim milk.

\section{Preparation of Cell-Free Extract}

The washed cells were resuspended in appropriate amount of $0.05 M$ Tris-HCl buffer (pH 7.5) and then disrupted by 3 passages through a French press cell at $18,000 \mathrm{psi}\left(1 \mathrm{psi}=703.0696 \mathrm{~kg} / \mathrm{m}^{2}\right)$. The enzyme extract was centrifuged $\left(15,000 \times \mathrm{g}, 35 \mathrm{~min}, 4^{\circ} \mathrm{C}\right)$ to eliminate cell debris, and the supernatant fraction was used as the intracellular crude enzyme.

\section{Proteinase Assay}

The proteinase activity conducted in replicate assays was measured using the chromogenic substrate, azocasein, according to the modified method of Beynon (1992). A portion $(100 \mu \mathrm{L})$ of $2 \%(\mathrm{wt} / \mathrm{vol})$ azocasein in $50 \mathrm{mM}$ sodium phosphate buffer ( $\mathrm{pH}$ 7.0) was mixed with 100 $\mu \mathrm{L}$ of enzyme in an Eppendorf tube. The mixture was incubated at $37^{\circ} \mathrm{C}$ for $16 \mathrm{~h}$, as the enzyme activity was linear over a 16 -h assay. The reaction was terminated by the addition of $500 \mu \mathrm{L}$ of $12 \%$ (wt/vol) TCA solution and mixed thoroughly. After $15 \mathrm{~min}$ at room temperature, the mixture was centrifuged at $12,000 \times g$ for 5 min. After $500 \mu \mathrm{L}$ of supernatant was added to $500 \mu \mathrm{L}$ of $1.0 \mathrm{M} \mathrm{NaOH}$, the absorbance was measured at 440 $\mathrm{nm}$ against a blank without enzyme. One unit of proteinase activity was defined as the amount of the enzyme that results in an increase of 0.01 absorbance per hour at $440 \mathrm{~nm}$.

\section{Protein Determination}

Protein content conducted in replicate assays was determined according to Smith et al. (1985). The bicinchoninic acid protein assay reagent supplied with the system (Pierce Chemical Ltd., IL) was used, with BSA as the standard. The protein concentrations in the fractions from the column were measured at $280 \mathrm{~nm}$.

\section{Purification of Enzyme}

The active enzyme fractions during the purification were stored at $4^{\circ} \mathrm{C}$ in the presence of stabilizers $(10 \%$ 
glycerol, $100 \mathrm{~m} M\left(\mathrm{NH}_{4}\right)_{2} \mathrm{SO}_{4}, 1 \mathrm{~m} M$ dithiothreitol). The intracellular crude enzyme was fractionated by salting out with ammonium sulfate ( 40 to $80 \%$ ) and centrifuged at $10,000 \times \mathrm{g}$ for $20 \mathrm{~min}$ at $4^{\circ} \mathrm{C}$. The precipitate was

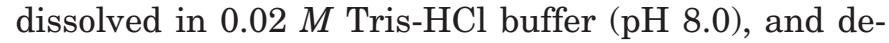
salted by Sephadex G-25 gel filtration (PD-10 column, Pharmacia) previously equilibrated with the same buffer. A Pharmacia fast protein liquid chromatography system was used for the purification.

First ion-exchange chromatography. The desalted crude extract was applied to a preparative Mono Q (HR 16/10) column equilibrated with $0.05 M$ Tris$\mathrm{HCl}$ buffer ( $\mathrm{pH}$ 8.0). The enzyme was eluted with a stepwise gradient of $\mathrm{NaCl}(0$ to $1.0 M$ ) in the same buffer at a flow rate of $3 \mathrm{~mL} / \mathrm{min}$. Fractions $(4 \mathrm{~mL})$ were collected and tested for the activity. Fractions with the highest enzyme activities were pooled, concentrated by ultrafiltration using a Centriprep-30 membrane, and desalted.

Second ion-exchange chromatography. The concentrated enzyme fraction was applied to the second ion-exchange (Mono Q HR 5/5) column equilibrated with $0.02 M$ bis-Tris-HCl buffer ( $\mathrm{pH}$ 6.4). The enzyme was eluted with a stepwise gradient of $\mathrm{NaCl}$ ( 0 to 1.0 $M$ ) in the same buffer at a flow rate of $0.75 \mathrm{~mL} / \mathrm{min}$, and $1.5-\mathrm{mL}$ fractions were collected. The active fractions were pooled, concentrated by ultrafiltration, and desalted.

Chromatofocusing. The active fraction was applied to a chromatofocusing Mono P column $(20 \mathrm{~cm} \times 0.5 \mathrm{~cm})$ after equilibration of the column with $20 \mathrm{~mL}$ of $0.02 \mathrm{M}$ bis-Tris-HCl buffer ( $\mathrm{pH}$ 6.0). The proteins were eluted with a linear $\mathrm{pH}$ gradient from 6.0 to 4.0 at a flow rate of $0.5 \mathrm{~mL} / \mathrm{min}$. The $\mathrm{pH}$ gradient was generated with a mixture of ampholytes (Polybuffer 7 to 4, Pharmacia), previously adjusted to $\mathrm{pH} 4.0$ with $6 \mathrm{MHCl}$. The $\mathrm{pH}$ value of the fractions was immediately adjusted to near neutral $\mathrm{pH}$ with $0.2 \mathrm{M}$ Tris-HCl buffer ( $\mathrm{pH} 7.5$ ) to minimize loss of enzyme activity. The polybuffer was removed from the active fractions by passage through a PD-10 column. The enzyme was concentrated using a Centricon-30 membrane.

Gel filtration chromatograpy. The enzyme was subjected to a gel filtration (Superose-12 HR 10/30) column equilibrated with $0.05 M$ Tris-HCl buffer ( $\mathrm{pH}$ 7.5). Elution was performed at a flow rate of $0.5 \mathrm{~mL} / \mathrm{min}$, and 1-mL fractions were collected. The active fractions were pooled and kept frozen at $-40^{\circ} \mathrm{C}$ for further studies.

\section{Hydrolysis of Caseins}

Reaction mixture consisted of 4 volumes of different caseins $\left(\alpha_{\mathrm{s} 1^{-}}, \beta\right.$-, and $\kappa$-CN) in $0.05 M$ phosphate buffer,
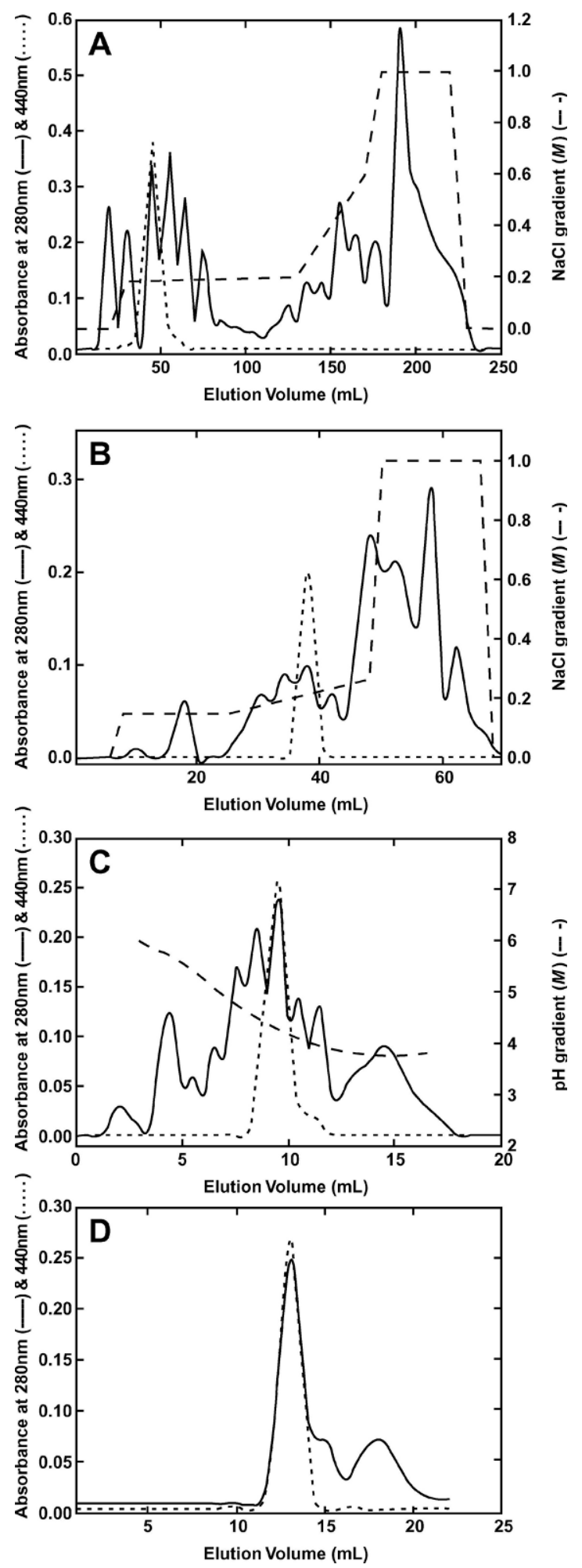

Figure 1. Purification of the intracellular proteinase from Lactobacillus casei ssp. casei LLG, protein concentration ( - ), enzyme activity (․), and $\mathrm{NaCl}$ or $\mathrm{pH}$ gradient (---). A) Mono Q HR 16/10, B) Mono Q HR 5/5, C) Mono P, and D) Superose 12 HR 10/30.

Journal of Dairy Science Vol. 87, No. 12, 2004 
Table 1. Summary of purification steps of proteinase from Lactobacillus casei ssp. casei LLG.

\begin{tabular}{lcccrc}
\hline $\begin{array}{l}\text { Purification } \\
\text { steps }\end{array}$ & $\begin{array}{c}\text { Total } \\
\text { Protein }(\mathrm{mg})\end{array}$ & $\begin{array}{c}\text { Total } \\
\text { Activity }\left(\mathrm{U}^{1}\right)\end{array}$ & $\begin{array}{c}\text { Specific } \\
\text { activity }^{2}(\mathrm{U})\end{array}$ & $\begin{array}{c}\text { Yield } \\
(\%)\end{array}$ & $\begin{array}{c}\text { Purification } \\
\text { (fold) }\end{array}$ \\
\hline Crude extract & 671.63 & 3513 & 5.2 & 100 & 1 \\
(NH $\left._{4}\right)_{2} \mathrm{SO}_{4} \mathrm{ppt}$ & 516.64 & 3402 & 6.6 & 97 & 1.3 \\
Ion exchange I & 43.61 & 1758 & 41.3 & 50 & 7.8 \\
Ion exchange II & 6.40 & 823 & 128.6 & 23 & 24.7 \\
Chromatofocusing & 1.45 & 556 & 383.4 & 16 & 73.7 \\
Gel filtration & 0.79 & 317 & 401.3 & 9 & 77.2 \\
\hline
\end{tabular}

\footnotetext{
${ }^{1}$ One unit of enzyme activity is defined as the amount of enzyme that results in an increase of 0.01 absorbance per hour at $440 \mathrm{~nm}$ under the assay condition.

${ }^{2}$ Specific activity is defined as enzyme units per milligram of protein.
}

$\mathrm{pH} 7.0$, and 1 volume of enzyme solution and incubated at $37^{\circ} \mathrm{C}$. Samples $(10 \mu \mathrm{L})$ were taken at $0,0.5,2,6$, and $12 \mathrm{~h}$. The protein samples were diluted (4:1) in sample buffer containing $62.5 \mathrm{mM}$ Tris-HCl, $\mathrm{pH} 6.8,2 \%$ (wt/ vol) SDS, $10 \%$ (vol/vol) glycerol, $0.005 \%$ (wt/vol) bromophenol blue, 5\% (vol/vol) 2- $\beta$-mercaptoethanol, and heated for $4 \mathrm{~min}$ at $95^{\circ} \mathrm{C}$ before applying to the gels.

\section{Polyacrylamide Gel Electrophoresis}

The purity of the enzyme preparation was examined by native and SDS-PAGE using the Phast System (Pharmacia). The SDS-PAGE was performed according to the method of Laemmli (1970). The molecular weight of the subunit of the purified enzyme was determined by SDS-PAGE using 12.5\% homogeneous PhastGel. The protein samples were mixed 1:1 with sample buffer $(20$ $\mathrm{m} M$ Tris-HCl, $\mathrm{pH}$ 8.0) containing $2 \mathrm{~m} M$ EDTA, 5\% SDS, $10 \% \beta$-mercaptoethanol and $0.001 \%$ (wt/vol) bromophenol blue, boiled for $4 \mathrm{~min}$ and applied to the gels. The low molecular weight proteins were used as standards for the predicting of molecular mass of the pure protein. The gels were stained with Coomassie blue-R 250.

\section{RESULTS}

\section{Purification of Enzyme}

Cell-free extracts obtained from the cytoplasmic fraction of $L b$. casei ssp. casei LLG were subjected to ionexchange (Mono Q HR 16/10 and Mono Q HR 5/5) columns, chromatofocusing (Mono P), and finally gel filtration column (Suprose 12 HR 10/30). The elution profiles during purification are shown in Figure 1.

The fractions eluted at 0.10 to $0.12 \mathrm{M} \mathrm{NaCl}$ gradient of Mono Q HR 16/10 ion-exchange chromatography were subjected to Mono Q HR 5/5 ion-exchange column. Then the fractions eluted at 0.16 to $0.18 \mathrm{M} \mathrm{NaCl}$ gradient of Mono Q 5/5 column were subjected to Mono P isoelectrofocusing column. The fractions eluted at 4.4 to $4.9 \mathrm{pH}$ gradient of Mono $\mathrm{P}$ column were subjected again to Superose 12 HR 10/30 gel filtration column. The scheme of purification is summarized in Table 1.
The enzyme was purified through 4 consecutive purification steps and appeared as a single band on SDSPAGE (Figure 2). The molecular weight of enzyme was estimated to be $55 \mathrm{kDa}$ by SDS-PAGE and gel filtration.

\section{Effects of $\mathrm{pH}$ and Temperature}

The effects of $\mathrm{pH}$ and temperature on the proteinase activity of purified enzyme were determined with azocasein. The appropriate amount of enzyme and substrate prepared in $0.05 \mathrm{M}$ acetate ( $\mathrm{pH} 5.5$ and 6.0), 0.05

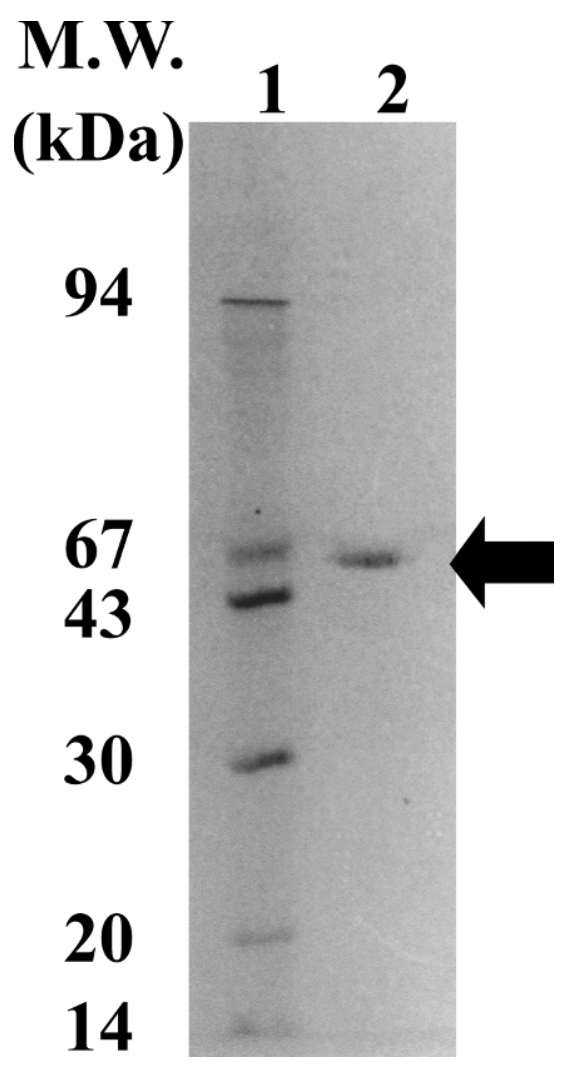

Figure 2. SDS-PAGE of the purified intracellular proteinase of Lactobacillus casei ssp. casei LLG on $12.5 \%$ polyacrylamide gel. Lane 1: molecular weight marker, Lane 2: purified enzyme. 


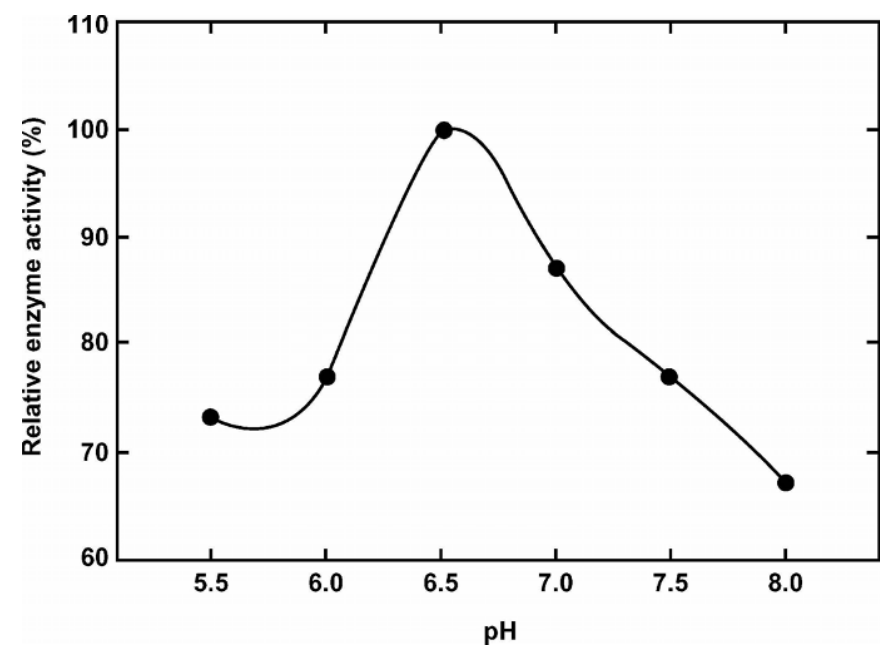

Figure 3. Effect of $\mathrm{pH}$ on the activity of intracellular proteinase from Lactobacillus casei ssp. casei LLG.

$M$ sodium phosphate ( $\mathrm{pH} 6.5$ to 7.0 ), $0.05 M$ Tris- $\mathrm{HCl}$ ( $\mathrm{pH} 7.5$ to 8.0) buffers were incubated at $37^{\circ} \mathrm{C}$, and the activity was measured. The appropriate amount of enzyme and substrate prepared in $0.05 \mathrm{M}$ phosphate buffer ( $\mathrm{pH}$ 6.5) were incubated at different temperatures $\left(25\right.$ to $\left.55^{\circ} \mathrm{C}\right)$, and the activity was measured. The optimal $\mathrm{pH}$ was about 6.5 , but at the $\mathrm{pH}$ less than 6.0 and higher than 7.5, the enzyme activity was sharply decreased (Figure 3). The optimal temperature of the purified enzyme was about $37^{\circ} \mathrm{C}$ (Figure 4). The relative activity at $25^{\circ} \mathrm{C}$ was less than $45 \%$, and about $20 \%$ of the activity was retained at $55^{\circ} \mathrm{C}$.

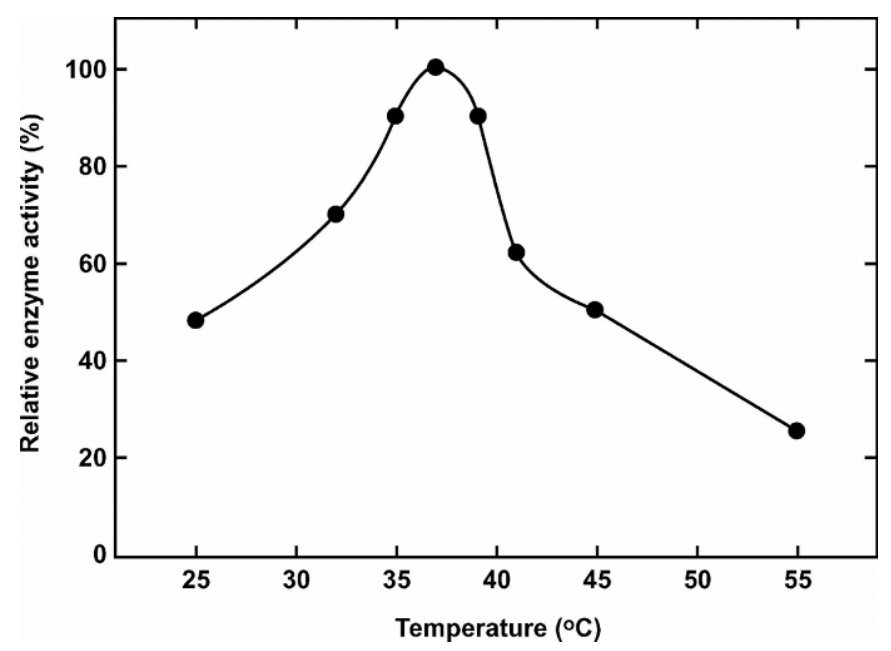

Figure 4. Effect of temperature on the activity of intracellular proteinase from Lactobacillus casei ssp. casei LLG.
Table 2. Effect of divalent cations and inhibitors on the proteinase activity.

\begin{tabular}{lc}
\hline Ion & Relative activity $(\%)^{2}$ \\
\hline Control & 100 \\
$\mathrm{CaCl}_{2}$ & 103 \\
$\mathrm{CoCl}_{2}$ & 109 \\
$\mathrm{CuSO}_{4}$ & 46 \\
$\mathrm{MnCl}_{2}$ & 128 \\
$\mathrm{MgCl}_{2}$ & 86 \\
$\mathrm{ZnCl}$ & 84 \\
$\mathrm{DIFP}$ & 84 \\
$\mathrm{PMSF}$ & 81 \\
EDTA & 26 \\
$1,10-$ Phenanthroline & 14 \\
Iodoacetamide & 94 \\
Iodoacetic acid & 92 \\
$\rho$-Chloromercuribenzoate & 44 \\
\hline
\end{tabular}

${ }^{1} 1.0 \mathrm{~m} M$ final concentration.

${ }^{2}$ Mean value of replicates.

\section{Effect of Divalent Cations and Inhibitors}

The effect of divalent cations on the proteinase activity of purified enzyme was determined by preincubation with a final concentration of $1 \mathrm{~m} M$ of cations in $0.05 \mathrm{M}$ sodium phosphate buffer ( $\mathrm{pH}$ 6.5) for $30 \mathrm{~min}$ at $37^{\circ} \mathrm{C}$ before addition of substrate. The effect of inhibitors on the activity of purified enzyme was determined by preincubation with a final concentration of $0.1,1.0$, and $10 \mathrm{~m} M$ of inhibitors for $30 \mathrm{~min}$ at $37^{\circ} \mathrm{C}$ before addition of substrate. Inhibition was expressed as a percentage of the activity without effector (control). The enzyme activity was strongly inhibited by $\mathrm{Cu}^{++}, \mathrm{Mg}^{++}$, and $\mathrm{Zn}^{++}$ at $1.0 \mathrm{~m} M$, but $\mathrm{Ca}^{++}, \mathrm{Co}^{++}$, and $\mathrm{Mn}^{++}$had no inhibitory effect. The activity was almost inhibited after the proteinase was treated with EDTA and 1,10-phenanthroline, but not strongly inhibited by phenylmethylsulfonylfluoride and diisopropylfluorophosphate treatment. The sulfhydryl group reagents, iodoacetic acid, and iodoacetamide had no significant effect on the proteinase activity (Table 2).

\section{Hydrolysis of Caseins}

The actions of intracellular proteinase of Lactobacillus casei ssp. casei LLG on $\alpha_{\mathrm{s} 1}-\mathrm{CN}, \beta-\mathrm{CN}$, and $\kappa$-CN were observed by SDS-PAGE. This enzyme hydrolyzed all caseins but seemed to be more active on $\beta$-CN than $\alpha_{\mathrm{s} 1}-\mathrm{CN}$ and $\kappa$-CN (Figure 5). In particular, $\beta$-CN was almost completely hydrolyzed by incubation for $12 \mathrm{~h}$ with this intracellular proteinase.

\section{DISCUSSION}

The proteolytic system (peptidases and proteinases) of lactic acid bacteria used in cheese making plays an 


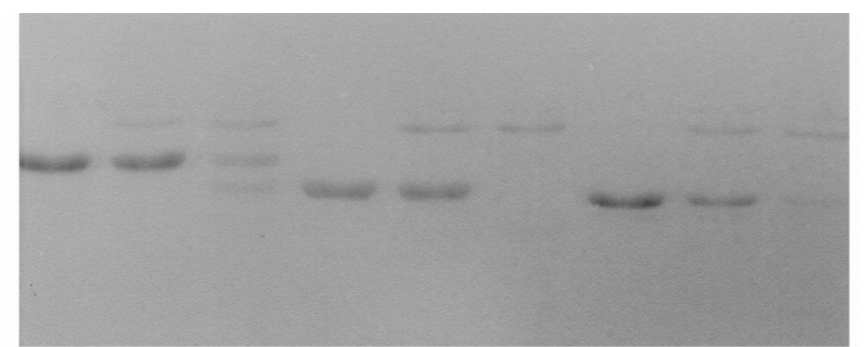

\section{$\begin{array}{lllllllll}\text { Std } & 0 & 24 & \text { Std } & 0 & 24 & \text { Std } & 0 & 24\end{array}$ $\alpha_{S 1}$-casein $\quad \beta$-casein $\quad \kappa$-casein}

Figure 5. SDS-PAGE on the action of intracellular proteinase from Lactobacillus casei ssp. casei LLG on $\alpha_{\mathrm{s} 1^{-}}, \beta$-, and $\kappa$-CN.

important role in the texture and flavor of the cheese, and it is well known that Lactococcus species are the most important starter used in cheese manufacture (Beresford et al., 2001). Despite the extensive works on the role of cell-envelope associated proteinase, the data on intracellular proteinase from lactic acid bacteria are limited.

The intracellular proteinase $L b$. casei ssp. casei LLG after several steps of purification showed that the purified enzyme is a monomeric enzyme with the apparent molecular mass of 55,000 as estimated by SDS-PAGE. Intracellular proteinases from other lactic acid bacteria were reported that Lc. lactis ssp. cremoris had a molecular mass of $140 \mathrm{kDa}$ (Ohmiya and Sato, 1975), and $L c$. lactis ssp. lactis NCDO 763 (Muset et al., 1989), and IAM 1198 (Akuzawa and Okitani, 1995) had a molecular mass of about 93 and $12 \mathrm{kDa}$, respectively. The sizes of intracellular proteinase from LAB appeared to be different among strains, and their function may also be different in cell. Maximum activity of intracellular proteinase from $L b$. casei ssp. casei LLG was obtained at $37^{\circ} \mathrm{C}$ and $\mathrm{pH} 6.5$. The enzyme properties were $\mathrm{pH}$ 6.5 to 7.0 and $30^{\circ} \mathrm{C}$ for Lc. lactis ssp. cremoris (Ohmiya and Sato, 1975), $\mathrm{pH} 7.5$ and $45^{\circ} \mathrm{C}$ for Lc. lactis ssp. lactis NCDO 763 (Muset et al., 1989), pH 5.5 to 6.0 and $30^{\circ} \mathrm{C}$ for Lc. lactis ssp. lactis IAM 1198 (Akuzawa and Okitani, 1995).

The enzyme was activated by $\mathrm{Ca}^{++}, \mathrm{Mn}^{++}$, and $\mathrm{Co}^{++}$, but inhibited by $\mathrm{Cu}^{++}, \mathrm{Mg}^{++}$, and $\mathrm{Zn}^{++}$that are in agreement with those of Lc. lactis ssp. cremoris (Ohmiya and Sato, 1975). This enzyme was also inactivated by metal chelating compounds (EDTA, 1,10-phenanthroline) and less affected by serine proteinase inhibitors (diisopropylfluorophosphate, phenylmethylsulfonylfluoride) and $\mathrm{SH}$-groups reagents (iodoacetamide, iodoacetic acid). These results indicate that this proteianse is a metalloenzyme characteristic, which agrees with those of Lc. lactis ssp. cremoris (Ohmiya and Sato,
1975) and Lc. lactis ssp. lactis NCDO (Muset et al., 1989) but does not agree with that of Lc. lactis ssp. lactis IAM 1198 (Akuzawa and Okitani, 1995).

Lactobacillus spp. are the major portion of the NSLAB in some cheeses. During ripening of Cheddar cheese, the intracellular proteolytic enzymes of Lactobacillus casei appeared to play an important role in protein breakdown after the death and lysis of the cells. Lactobacillus casei has the peptidolytic, esterolytic, and proteolytic activities (Roy et al., 1997), thus the use of Lactobacillus as adjunct cultures has gained much attention recently in the production of accelerated ripened cheese and enzyme-modified cheese (Arora et al., 1995; Park et al., 1995; Habibi-Najafi and Lee, 1996).

This enzyme hydrolyzed all milk casein fractions, but hydrolyzed $\beta$-CN more preferentially. On the basis of degradation patterns of $\alpha_{\mathrm{s} 1^{-}}, \beta$ - and $\kappa$ - $\mathrm{CN}, 2$ proteinase specificity classes may be possible as in Lactococci, but their comparisons are meaningless as they are unrelated enzymes. This proteinase probably involves later stage in the proteolysis of cheese curd after cell lysis. Intracellular proteinases are probably important in the turnover of denatured protein, activation of zymogens, and termination of newly synthesized proteins (Muset et al., 1989).

\section{REFERENCES}

Akuzawa, R., and A. Okitani. 1995. Purification and characterization of a cysteine proteinase with low activation energy from Lactococcus lactis ssp. lactis IAM 1198. J. Dairy Sci. 78:2609-2616.

Arora, G., and B. H. Lee. 1994. Purification and characterization of aminopeptidase from Lactobacillus casei subsp. casei LLG. J. Dairy Sci. 75:700-710.

Arora, G., F. Cormier, and B. H. Lee. 1995. Analysis of odor-active volatiles in Cheddar cheese headspace by multidimensional GC/ MS/Sniffing. J. Agric Food Chem. 43:748-752.

Belanger, E. 1998. Genetic identification of the Lactobcillus species using PCR-based PepN sequences. M.Sc. Thesis, McGill University, Montreal, QC, Canada.

Beresford, T. P., N. A. Fitsimons, N. L. Brennan, and T. M. Cogan. 2001. Recent advances in cheese microbiology. Int. Dairy J. 11:259-274.

Beynon, R. J. 1992. Prevention of uncontrolled proteolysis. Pages 40 51 in Protein Purification Methods: A Practical Approach. IRL Press, New York, NY.

Buist, G., G. Venema, and J. Kok. 1998. Autolysis of Lactococcus lactis is influenced by proteolysis. J. Bacteriol. 180:5947-5953.

Christensen, J. E., E. G. Dudley, J. A. Pederson, and J. L. Steele. 1999. Peptidases and amino acid catabolism in lactic acid bacteria. Antonie van Leeuwunhoek 76:217-246.

Courtin, P., M. Nardi, U. Wegmann, V. Joutsjoki, J. C. Ogier, J. C. Gripon, A. Palva, B. Henrich, and V. Monnet. 2002. Accelerating cheese proteolysis by enriching Lactococcus lactis proteolytic system with Lactobacillus peptidases. Int. Dairy J. 12:447-454.

Dako, E., M. El Soda, J.-C. Vuillemard, and R. E. Simard. 1995. Autolytic properties and aminopeptidase activities of lactic acid bacteria. Food Res. Int. 28:503-509.

Demarigny, Y., E. Beuvier, A. Dasen, and G. Duboz. 1996. Influence of raw milk microflora on the characteristics of Swiss-type cheeses. I. Evolution of microflora during ripening and characterization of facultatively heterofermentative lactobacilli. Lait 76:371-387. 
Dhingra, J., and S. M. Dutta. 2000. Isolation, purification and characterization of the cell envelope associated proteinase of Lactobacillus casei 300. Indian J. Dairy Sci. 53:177-183.

El Abboudi, M., S. Pandian, G. Trépanier, R. E. Simard, and B. H Lee. 1991. Heat-shocked lactobacilli for the acceleration of Cheddar cheese ripening. J. Food Sci. 56:946-949 and 953.

El Soda, M., M. J. Desmazeavd, D. Le Bars, and C. Zevaco. 1986. Cell-wall-associated proteinase in Lactobacillus casei and Lactobacillus plantarum. J. Food Prot. 49:361-365.

Ezzat, N., M. El Soda, and H. El Shafei. 1988. The cell-bound proteinase system of Lactobacillus casei-purification and characterization. Int. J. Food Microbiol. 6:327-332.

Fitzsimons, N. A., T. M. Cogan, S. Condon, and T. Beresford. 1999. Phenotypic and genotypic characterisation of non-starter lactic acid bacteria in matured Cheddar cheese. Appl. Environ. Microbiol. 65:3418-3426.

Geis, A., W. Bockelmann, and M. Teuber. 1985. Simultaneous extraction and purification of a cell wall-associated peptidase and $\beta$ casein specific protease from Streptococcus cremoris AC1. Appl. Microbiol. Biotechnol. 23:79-84.

Habibi Najafi, M. B., and B. H. Lee. 1994. Purification and characterization of x-prolyldipeptidyl peptidase from Lactobacillus casei ssp casei LLG. Appl. Microbiol. Biotech. 42:280-286.

Habibi-Najafi, M. B, and B. H. Lee. 1996. Bitterness in cheese: A Review. Crit. Rev. Food Sci. Nutr. 36:397-411.

Johnson, J. A., M. R. Etzel, C. M. Chen, and M. E. Johnson. 1995. Accelerated ripening of reduced-fat Cheddar cheese using four attenuated Lactobacillus helveticus CNRZ-32 adjuncts. J. Dairy Sci. 78:769-776.

Jordan, K. N., and T. M. Cogan. 1993. Identification and growth of non-starter lactic acid bacteria in Irish Cheddar cheese. Irish J. Agric. Food Res. 32:47-55.

Kang, O. J., L. P. Vezinz, S. Laberge, and R. E. Simard. 1998. Some factors influencing the autolysis of Lactobacillus bulgaricus and Lactobacillus casei. J. Dairy Sci. 81:639-646.

Kawai, Y., K. Tadokoro, R. Konomi, K. Itoh, T. Saito, H. Kitazawa, and T. Itoh. 1999. A novel method for the detection of protease and the development of extracellular protease in early growth stages of Lactobacillus delbrueckii ssp. bulgaricus. J. Dairy Sci. 82:481-485.

Laemmli, U. K. 1970. Cleavage of structural proteins during the assembly of the head of bacteriophage T4. Nature (Lond.) 227:680-685.

Lee, B. H., L. C. Laleye, R. E. Simard, M. H. Munsch, and R. A. Holley. 1990a. Influence of homofermentative lactobacilli cultures on the evolution of the microflora and soluble nitrogen compounds in Cheddar cheese. J. Food. Sci. 55:391-397.

Lee, B. H., L. C. Laleye, R. E. Simard, R. A. Holley, D. B. Emmons, and R. N. Giroux. 1990b. Influence of the homofermentative lactobacilli cultures on physico-chemical and sensory properties of Cheddar cheese. J. Food Sci. 55:386-390.
Lee, B. H., and N. Robert. 1997. Overexpression of Lactobacillus rhamnosus aminopeptidase in $E$. coli (U.S patent file no. 60/ 025,172).

Linberg, A. M., A. Christiansson, E. O. Rukke, T. Eklund, and G. Molin. 1996. Bacterial flora of Norwegian and Swidish semi-hard cheese after ripening, with special reference to Lactobacillus. Neth. Milk Dairy J. 50:563-572.

Madkor, S. A., P. S. Tong, and M. El Soda. 2000. Ripening of Cheddar cheese with added attenuated adjunct cultures of lactobacilli. J. Dairy Sci. 83:1684-1691.

McSweeney, P. L. H., E. M. Walsh, P. F. Fox, T. M. Cogan, F. D. Drinan, and M. Castelo-Gonzalez. 1994. A procedure for the manufacture of Cheddar cheese under controlled bacteriological conditions and the effect of adjunct lactobacilli on cheese quality. Irish J. Agric. Food Res. 33:183-192.

Muset, G., V. Monnet, and J.-C. Gripon. 1989. Intracellular proteinase of Lactococcus lactis subsp. lactis NCDO 763. J. Dairy Res. 56:765-778

Nath, K. R., and R. A. Ledford. 1973. Growth response of Lactobacillus casei variety casei to proteolysis products in cheese during ripening. J. Dairy Sci. 16:710-715.

Ohmiya, K., and Y. Sato. 1975. Purification and properties of intracellular proteinase from Streptococcus cremoris. Appl. Microbiol. 30:738-745.

Park, S. Y., B. F. Gibbs, and B. H. Lee. 1995. Effect of crude enzyme of Lactobacillus casei LLG on water-soluble peptides of enzymemodified cheese. Food Res. Int. 28:43-49.

Roy, D., M. Pitre, L. Blanchette, L. Savoie, G. Belanger, P. Ward, and J. L. Maubois. 1997. Monitoring proteolysis and cheese juice composition during ripening of Cheddar cheese made from microfiltered milk. Lait 77:521-541.

Siezen, R. J. 1999. Multi-domain, cell-envelope proteinases of lactic acid bacteria. Antonie van Leeuwenhook 76:139-155.

Smith, P. K., R. I. Krohn, G. T. Hermanson, A. K. Mallia, F. H. Gartner, M. D. Provenzano, E. K. Fujimoto, N. M. Geoke, B. J. Olson, and D. C. Klenk. 1985. Measurement of protein using bicinchroninic acid. Anal. Biochem. 150:76-85.

Thomas, T. 1987. Cannibalism among bacteria found in cheese. N.Z. J. Dairy Sci. Technol. 22:215-219.

Trépanier, G., M. El Abboudi, B. H. Lee, and R. E. Simard. 1992a. Accelerated maturation of Cheddar cheese: Microbiology of cheese supplemented with Lactobacillus casei. J. Food Sci. 57:345-349.

Trépanier, G., M. El Abboudi, B. H. Lee, and R. E. Simard. 1992b. Accelerated maturation of Cheddar cheese: Influence of added lactobacilli and commercial protease on composition and texture. J. Food Sci. 57:898-902

Valence, F., R. Richoux, A. Tierry, A. Palva, and S. Lortal. 1998. Autolysis of Lactobacillus helveticus and Propionibacterium freudenreichii in Swiss cheese: First evidence by using species-specific lysis markers. J. Dairy Res. 65:609-620.

William, A. G., and J. M. Banks. 1997. Proteolytic and other hydrolytic enzyme activities in non-starter lactic acid bacteria (NSLAB) isolated from Cheddar cheese manufactured in the United Kingdom. Int. Dairy J. 7:763-774. 